Rapp. Grønlands geol. Unders. 48, 21-37 (1972)

\title{
PRELIMINARY RESULTS OF MAPPING IN THE CALEDONIAN ROCKS OF CANNING LAND AND WEGENER HALVØ, EAST GREENLAND
}

\author{
R. Caby
}

\section{Introduction}

The pre-Middle Devonian sediments and igneous rocks of Canning Land and Wegener Halvø $\left(120 \mathrm{~km}^{2}\right)$ were remapped in detail at a scale of 1:50000 (map 2) during eight weeks of excellent weather in the summer of 1971. This area includes fragments of Caledonian superstructure bounded to the west by Middle Devonian clastics and the Mesozoic terrain of Jameson Land.

Canning Land and Wegener Halvø have previously been investigated by Nordenskjöld (1907), who gave the first geological map, Noe-Nygaard (1937), who carried out petrographical investigations on the igneous rocks, and Bütler (1948), who presented a coherent picture of the stratigraphy and structural geology and a detailed map.

The area mapped includes the southernmost outcrops of the Caledonian superstructure (Eleonore Bay Group, Tillite Group and Cambro-Ordovician) occurring at the easternmost exposed edge of the Caledonian fold belt, where they are elevated by post-Devonian block-faulting. According to Bütler (1948, p. 20) Canning Land forms "part of the elevated edge of the Liverpool Land block, but owing to the slighter elevation it escaped erosion". All the other pre-Devonian rocks in Scoresby Land and Liverpool Land apparently belong to deeper structural levels of the Caledonian infrastructure.

New stratigraphic and structural investigations in the area were necessary: a) for a comparison with the classical stratigraphic succession in Strindbergs Land and in the Alpefjord region described by Katz (1952) and Fränkl (1953), and possibly with the metasedimentary sequence found in Liverpool Land; b) for a general understanding of the depositional conditions of the Eleonore Bay Group.

\section{Stratigraphy}

About $5000 \mathrm{~m}$ of the Eleonore Bay Group have been recorded, succeeded by the Eocambrian tillite and Cambrian strata $(800 \mathrm{~m})$, which are unconformably overlain by sediments and tuffs of the basal part of the Devonian succession. 
The Precambrian succession is very similar to that of the Alpefjord region, and the standard nomenclature and numbering (Bed groups 1-20) introduced by Katz (1952) and Fränkl (1953) can be applied in Canning Land for the higher part of the Upper Eleonore Bay Group. The basal part of the Quartzite Series and the Lower Eleonore Bay Group cannot be correlated without difficulty, and seem everywhere to be separated from the upper part by faults.

\section{Lower Eleonore Bay Group}

The Lower Eleonore Bay Group $(>2000 \mathrm{~m}$ ) consists of monotonous black shales and quartzitic shales and slates. The succession mentioned below is based on geometrical considerations; the beds are affected by different degrees of mylonitisation, and slides of unknown size are inferred from the mylonitic stratoïd zones, where the rocks are transferred to slates. Moreover, the contact metamorphism around the Kap Wardlaw granite is strongly developed in the shales, and the numerous faults which affect the area make correlations difficult.

The lowermost part $(>400 \mathrm{~m})$ exposed in the east (Kap Wardlaw and Bowen Bjerg) is characterised by its massive aspect and its white to pale pink weathering. Thinly laminated quartzites can form $25 \%$ to $50 \%$ of the rock, and are associated with more shaly dark blue to black compact rocks. Small deep channels (up to $20 \times 20 \mathrm{~cm}$ in transverse sections) of brown-weathered ankeritic sandstone are frequent and some poorly preserved mud-cracks have been observed. The overlying beds $(>600 \mathrm{~m})$ comprise black shales, with frequent thin laminations or pseudo-varves followed by 2 regular beds of layered quartzite (70 and $100 \mathrm{~m}$ ).

The succession exposed between Dobbeltvigen and Århus Bugt may represent either a repetition of the same succession or higher levels of the series above the layered quartzites. Compact black to dark blue quartzitic shales with rusty pink weathering and including numerous small lenses and channels of ankeritic sandstone $(250 \mathrm{~m})$, are overlain by soft, flaggy black shales, and psammitic shales with pyritic and carbonaceous zones. Poor in sedimentary features, these rocks show frequently a phyllonitic fabric, while the compact lower shales show an incipient sub-vertical flow cleavage.

The succession exposed East of Porfyrdal $(500 \mathrm{~m})$ may constitute the higher parts of the Lower Eleonore Bay Group. A massive quartzite $(50 \mathrm{~m})$, pink and conglomeratic at the top, is followed by a few metres of dark green chloriticglauconitic (?) shales and siltstones and overlain by $300 \mathrm{~m}$ of flaggy black shales particularly rich in small, deep E-W oriented channels of brown ankeriticmanganesiferous(?) sandstone; some sun-cracks have been observed. A second, regular, well banded and cross-bedded quartzite $(60 \mathrm{~m})$ with mud pebbles at the top is overlain by at least $100 \mathrm{~m}$ of green to khaki shales and silty shales with thin manganesiferous sandstone laminations, and rare $\mathrm{Cu}$-bearing shales. 
The whole succession (at least $2000 \mathrm{~m}$ ) shows a very uniform pattern and no lithostratigraphic subdivision has been possible.

The occurrence of sun-cracks, also recognised by Bütler (1948, p. 22), small ripple-marks, and the presence of the very constant and conspicuous small channels of sandstone with sub-vertical walls cutting through the shaly layers (calling to mind small "wash-out" structures of the Carboniferous) suggest a depositional environment of either a shallow basin of sub-continental type, or a vast deltaic and sub-tidal shelf. It seems unlikely that this corresponds to the Upper ArgillaceousArenaceous Series of the fjord zone; however, the higher part of the succession exposed east of Porfyrdal may represent the beginning of the Quartzite Series with its green characteristic shaly layers.

The black quartzitic shales of Kap Brown overlie green shales and silty shales similar to those of the Quartzite Series with a conformable tectonic contact. One kilometer north of Tvekegledal along the coast, similar black and dark green shales contain boudinaged, coarse-grained carbonate lenses, which possibly are the equivalent of the Calc-Argillaceous Series.

\section{Upper Eleonore Bay Group}

\section{Quartzite Series}

The Quartzite Series $(>1500 \mathrm{~m})$ is nowhere exposed in one single section, and the quartzitic layers are never as thick as those reported in the classical sections of the fjord region. On the northern side of Ålborg Fjord, its lowermost part (500 m bed $1(?))$ begins with white banded quartzites $(100 \mathrm{~m})$, followed by black and typical green shales and silty shales with frequent varve structures and compact chloritic and silty thin bands. Numerous lenticular sulphide occurrences of primary origin and impregnations (pyrite and chalcopyrite) have been encountered. Above follows a massive white quartzite $(100 \mathrm{~m}-$ bed $2(?))$ which is possibly the same bed as that south-east of Kap Tyrrel, where it forms the bottom of a structural unit (fig. 3). The overlying beds $(200 \mathrm{~m})$ south of Kap Tyrrel are black shales and micaceous shales with some regular bands $(2-10 \mathrm{~m})$ of white quartzite. The succeeding varicoloured red, purple and green banded formation (beds 3-6, $550 \mathrm{~m}$ ) contrasts sharply with the underlying black shales. They comprise compact banded shales and silty shales, and micaceous shales with thin laminations and lenses of quartzite $(0.1$ to $5 \mathrm{~cm}$ ) alternating with regular bands of white spotted sandstone (1 to 20 m) showing typical small limonitic-ankeritic dots (Eha, 1953, p. 17). In the red shales, ripple-marks and current bedding with a mean direction of transport towards NNW are frequent north of the valley of Snevigen. In the main green layer of shales, micaceous silty shales and banded green quartzites, thin films and lenses of unweathered, dark, fine-grained copper ore (chalcosine) have been encountered in the south-eastern flank of Kap Tyrrel. The top of the succession includes dark 
green compact and chloritic silty shales, in which some large-scale cross-bedding and slumping occur, alternating with black shales and regular bands of dotted ankeritic white sandstone (top of bed 6).

\section{Multicoloured Series}

The sequence in Canning Land $(750-900 \mathrm{~m})$ shows the same succession as in the fjord region and includes bed groups 7 to 13 . The bed group $7(150 \mathrm{~m})$ is made of a characteristic alternation of red and purple shales and silty shales, which show towards the top gradual transitions into dolomitic silty shales with bands of limestone or dolomite. In the red-purple shales, sun-cracks and small channels of brown-weathered sandstone similar to those described above are frequent. A conspicuous regular green band of quartzitic, copper bearing silty shale $(2 \mathrm{~m})$ which appears $30 \mathrm{~m}$ beneath the first yellow dolomites, seems to be the same, layer as recorded in Strindbergs Land (Katz, 1952, p. 64).

The bed group $9(100 \mathrm{~m})$ is a grey, fetid, bituminous limestone layer with numerous chert lenses. Monogenic breccias and bioclastic beds alternate with varved dolomitic limestones in which the earliest in situ oncolite colonies and stromatolitic layers have been found. The beds 10 to $11(150 \mathrm{~m})$ are yellow dolomites, with polygenic breccias, white limestones and red siltstones, various banded grey limestones and dolomites overlain by black to dark green shales which gradually pass into yellow dolomites.

The bed group $12(200 \mathrm{~m})$ is a massive grey dolomite, which partly or completely replaces black bituminous and fetid limestones. At its top, the first algal biostromes occur in white, yellow or pink bands of dolomite which constitute very regular bands made up of large, branched, columnar stromatolites. The bed group 13 is a massive white quartzite $(100 \mathrm{~m})$ rich in ripple-marks and cross-bedding, and overlain by yellow stromatolitic biostromes and black shales $(20 \mathrm{~m})$, and $40 \mathrm{~m}$ of alternating sandstones and grey dolomites with pink dolomitic layers of stromatolite dolomite. The algal biostromes of bed groups 12-13 are strikingly similar to those of the fjord region (Katz, 1952, p. 81; Eha, 1953, p. 20) and imply very uniform, sub-tidal depositional conditions over immense areas of the basin.

In contrast to the fjord region, red colours are restricted to bed 7, the lower part of bed 10 and some pink dolomitic layers with thin ferruginous bands in bed group 13.

The higher part of bed group 7 suggests general positive conditions followed by shelf-type marine conditions represented by bed groups 9 to 12, whose limestones are lithologically identical to those of the bed groups 14-17 of the LimestoneDolomite Series. Higher in the succession no traces of emergence (sun-cracks) are found in Canning Land. It is considered that the most important break in depositional conditions, representing the first marine transgression, should be placed at the base of bed group 9 in agreement with Bütler (1948). 


\section{Limestone-Dolomite Series}

The succession is principally exposed south of Ålborg Fjord and at Kap Fletcher and comprises bed groups 14-19 $(900 \mathrm{~m})$. The lower part (bed groups 14-17: 650 m) consists of various dolomites and limestones rich in ooïds, stromatolitic layers, bioclastic layers, black cherts and intraformational flake-breccias. Dark grey to black, often bituminous and carbonaceous limestones, very similar to those of bed groups 9 to 12, form 5 or 6 recurring layers, partly replaced by pale grey secondary dolomite; white-weathered, fine-grained, dark grey dolomitic layers, 2 to $15 \mathrm{~m}$ thick also occur, rich in intraclasts or organic remains. Five white regular bands (often boudinaged) are partly or totally composed of small columnar and branched stromatolites and bioclastic layers. The upper part ( $250 \mathrm{~m}$ - bed group 18 (?)) consists of a massive, primary, white dolomite with some stromatolitic layers, in which numerous black or grey cherts appear towards the top. The last layers exposed consist of 10 to $20 \mathrm{~m}$ of black shales and black, irregular, cherty bands interbedded with grey dolomitic bands (bed group 19 (?)). The sedimentary features of this succession suggest shelf-type marine conditions. The stromatolitic biostromes imply large areas located in quiet conditions of the sub-tidal zone. The bioclastic facies, in which stromatolitic fragments, ooïds and other enigmatical remains have been found, are typical of high energy deposits washing out quiet deposits. High $\mathrm{H}_{2} \mathrm{~S}$ and carbon contents suggest an intensity of biological activity surprising for Upper Precambrian times. Systematic studies on stromatolites and other organic remains will be presented later together with sedimentological and stratigraphical results.

The Precambrian Eleonore Bay Group succession is conformably overlain by Eocambrian and Cambrian strata which have been discovered west of Kap Fletcher.

\section{Tillite Group}

The Tillite Group is a banded unit $60 \mathrm{~m}$ thick comprising 6 tillitic horizons. They comprise structureless and varved pebbly siltstones and mudstones of red, dark green or black colour, together with unsorted erratic blocks, and alternate with bands of yellow-weathered white sandstone. A main layer of sandstone $(15 \mathrm{~m})$ divides the succession. The sub-rounded erratic blocks up to $0.50 \mathrm{~m}$ diameter are Eleonore Bay Group rocks (limestones, dolomites, quartzites); rare red granite blocks occur in the higher, red tillite bands. No striated boulders have been found. According to many geologists, this tillite of very uniform character in East and north-east Greenland could represent glacial sediments deposited by glaciers of Antarctic shelf-ice type. 


\section{Cambrian}

A white massive quartzite $(80 \mathrm{~m})$, red and hematitic at the top, overlies the tillite conformably; many ripple-marks occur in the lower part. Succeeding green pyritic siltstones and red silty sandstones $(100 \mathrm{~m}$ ) are sharply limited by a massive, red, shelly limestone band $(5 \mathrm{~m})$ in which the first fossils have been found. There follows $40 \mathrm{~m}$ of khaki siltstones with thin, regular, shelly limestone bands. The fossils found include small brachiopods, pieces of Ollenellidae (?) in the first layer, and one small trilobite, Obolella congesta (kindly determined by V. Poulsen), found in green siltstones $30 \mathrm{~m}$ above the first shelly band. In the following $130 \mathrm{~m}$ of green, black and often micaceous shales and quartzitic shales, many similar shelly limestone bands occur. This succession, to which a provisional Lower Cambrian age can be assigned, may be correlated with the Lower and Upper Bastion Formation of the fjord region; Obolella congesta indicates the highest fossil-bearing part of the Bastion Formation (Poulsen, 1930).

The following ochre-weathered, grey, flysch-like succession $(100 \mathrm{~m})$ begins with sandy siltstones or limestones and dolomitic silty shales. Thin, regular, rhythmic sedimentation with constant micro-cross-bedding is the rule, even in thick massive beds. Slumping and mega-slump-balls occur in the dolomites. This turbulent, fossiliferous, rhythmic sedimentary sequence, which may possibly be correlated with the Ella $\emptyset$ Formation, stops sharply.

The overlying yellow-weathered, banded dolomites and limestones $(50 \mathrm{~m})$ with black shaly bands may be correlated with the Hyolithes Creek Formation.

The pale-grey massive dolomites $(250 \mathrm{~m})$ which follow are possibly the equivalent of the Dolomite Point Formation of Middle Cambrian age. In the banded dolomites $(10$ to $40 \mathrm{~cm}$ ) with secondary coarse-grained recrystallisation, only oolites, flake-breccias and typical traces of bioturbation have been found.

The $150 \mathrm{~m}$ of yellow or grey massive dolomites with polygenic breccias, numerous black oolitic cherts, and the quartzite lenses exposed west of Porfyrbjerg are the last pre-Devonian beds exposed in Canning Land, and are of Middle Cambrian to Lower Ordovician age.

\section{Lower to Middle Devonian}

The Lower to Middle Devonian rocks are principally exposed east of Søndre Basisdal, and appear beneath the main volcanic flows.

A basal unconformity is locally preserved; the Eleonore Bay Group limestones or dolomites beneath have suffered a characteristic silicification and have a brown colouration.

The succession found near the top of the $600 \mathrm{~m}$ high Kap Fletcher comprises: 1) pebbly ankeritic sandstones, polygenic breccias and varved ochre and yellow 
dolomites $(1-10 \mathrm{~m})$; 2) highly slumped and microfolded dolomites and dolomitic siltstones invaded by irregular cherts and siliceous networks $(10-30 \mathrm{~m})$; 3) black varved shales $(20 \mathrm{~m})$.

Farther to the west, these beds are found as lenses in the basal part of a $200 \mathrm{~m}$ thick monotonous succession of grey-green biotitic tuffs, pebbly tuffs, arkoses and volcanic sandstones; but also as moved, highly deformed, slumped and chaotic masses (olistolites) in the middle part of these same volcanic tuffs. The last sediments found above the tuffs are black carbonaceous shales and sandstones (30 m) north-east of Søndre Basisdal. The grey-green biotitic tuffs are the same as those described in Porfyrbjerg by Noe-Nygaard (1937). In the south-west face of this mountain, the succession is as follows: 1) lenses of polygenic conglomerates or dolomitic breccias in a yellow dolomitic matrix $(0-30 \mathrm{~m})$, locally preserved in situ overlying black shales of the Eleonore Bay Group; 2) white, coarse-grained, hypovolcanic rhyolite with conspicuous, large-scale, recumbent flow folds striking $\mathrm{N}$ to $\mathrm{NE}$, and with breccia structure at the bottom $(50-300 \mathrm{~m}) ; 3)$ pink, pebbly, arkosic sandstones and tuffs unconformably overlying $2(0-50 \mathrm{~m}) ; 4)$ biotitic, grey-green, flattened pebbly tuffs with volcanic elements interpreted as volcanic bombs by Noe-Nygaard (1937, p. 94: 50-120 m).

In Wegener Halvø, the only sediments recorded beneath the red lavas are polygenic, ankeritic, coarse conglomerates north-east of Vimmelskaftet. Also in the faulted zone between Eleonore Bay Group rocks and the red lavas of Kap Brown, a succession $30 \mathrm{~m}$ thick occurs of banded dolomites, limestones, black carbonaceous shales and quartzitic shales similar to those north-east of Søndre Basisdal.

\section{Red and green porphyries}

This series is petrographically well known from the work of Noe-Nygaard (1937). The complex includes rhyodacites and latites but has not been reinvestigated in detail. The thickness of these stratified lavas, west of Kap Fletcher, is possibly about $1000 \mathrm{~m}$, with chaotic breccia lavas at the bottom, suggesting an immediate proximity to a volcanic cone. In Porfyrfjeld these "porphyries" seem to consist of a main flow (400-500 m) with large-scale flow folds at the bottom, overlying unconformably the tuffs with an undulating topography.

In the Søndre Basisdal complex, the occurrence of coarse-grained, quartz alkali feldspar miarolitic patches and flecky segregations in banded lavas suggests that most of the succession was overlain by a thick pile of volcanics, which allowed slow recrystallisation under hypo-volcanic conditions. 


\section{Pre-Middle Devonian intrusive rocks}

Many successive generations of dykes can be distinguished and some of their mutual relations with Kap Fletcher volcanics and the Kap Wardlaw granite can be defined.

\section{Doleritic sills and dioritic sheets of Wegener Halvo}

These fresh rocks are bordered by spotted slates for some $10 \mathrm{~m}$ or so around. Their relationships with lamprophyric rocks could not be observed in the steep eastern cliff of Kap Brown, but these rocks seem to be the earliest intrusions in Wegener Halvø.

\section{Lamprophyric dykes and sills}

Dykes and sills of lamprophyric type were encountered everywhere and measured from 0.5 up to $30 \mathrm{~m}$ in thickness. Generally deeply weathered they occur as the filling of normal fault planes, sometimes gently inclined, and as dyke swarms striking NW-SE near the limit of the Devonian graben; they are particularly numerous in the Lower to Middle Devonian tuffs and sediments. Their emplacement probably relates to the maximum extension of the graben tectonics accompanying the end of volcanism. They are often affected by subsequent shearing. Some microsyenitic differentiation occurs.

At Kap Wardlaw and on Wegener Halvø the same rocks occur as dykes and sills, very frequently in association with porphyric, leuco-calc-alkaline microgranite and micro-quartz-diorite, and without any chilled zone between both magmas in a same channel. Some of them show a strong foliation and an intense recrystallisation with secondary biotite and amphibole. These complex dykes occur as pre-granitic forerunners and apophyses, sometimes related to dioritic apophyses. The basic and semi-basic rocks show all degrees of assimilation by the biotite granite and survive as small sub-spherical xenoliths in granite, more commonly in the biotitehornblende mesocratic granite or granodiorite.

\section{Kap Wardlaw granite}

The Kap Wardlaw granite cuts the black shale with sub-vertical contacts and has irregular convex lobes and apophyses up to $600 \mathrm{~m}$ in length. All gradual transitions have been observed between granodiorite, biotite granite (most common), leucocratic granite and porphyric microgranite. The main xenoliths are: 1) melanocratic amphibole-biotite rocks of dioritic or lamprophyric origin generally less than $5 \mathrm{~cm}$ across; 2) metasediments, country rock biotite hornfelses and foreign biotite-bearing schists and gneisses with sillimanite, cordierite, green spinel and corundum.

Leucocratic-alaskite differentiation products cut the granite as dykes. Two post- 
granitic, melanocratic lamprophyric dykes (pre-Tertiary) have also been encountered.

The whole massif is affected by post-magmatic E-W jointing outlined by a red staining, chloritisation, and gashes filled by hydrothermal quartz, chlorite, calcite, barytes and pyrite of possible Tertiary age.

Contact metamorphism is seen as: 1) a zone of spotted slates 250 to $400 \mathrm{~m}$ wide surrounding the granite; 2) a zone of biotite \pm andalusite hornfelses $(20-150 \mathrm{~m}$ wide); in some cases, biotite occurs in axial planes of minor folds, suggesting a synkinematic growth; 3) a zone of high-grade cordierite \pm garnet \pm sillimanite biotite hornfelses to gneisses $(0$ to $20 \mathrm{~m}$ ), with diffuse granitisation (or dioritisation), flow folding, agmatitic and migmatitic breccias, and mineral segregations.

Pneumatolytic processes have induced in aluminous rocks tourmaline \pm muscovite \pm biotite aplite or pegmatite veins closely emplaced in the metamorphic zones $\mathbf{2}$ or $\mathbf{3}$ in late extension fractures. In calc-silicate quartzites, basic plagioclase + diopside + green amphibole pegmatitic veinlets have also been encountered.

Porphyritic microgranite and microsyenite dykes

The dykes are found at Kap Fletcher cutting limestones and dolomites. Some are 40 to $60 \mathrm{~m}$ thick, with a dip of $45^{\circ}$ to east. They cut the lamprophyric dykes and the lavas, and may represent the last magmatic event prior to Middle Devonian time.

\section{Structure}

In most places, the pre-Devonian sediments are weakly folded or sub-horizontal, with a general dip to the NW in Kap Tyrrel, and W or SW in the Kap Fletcher area. In appearance the features are very typical of the superstructure of the Central East Greenland Caledonian fold-belt, characterised by open folds apparently due to vertical movements (Haller, 1970, p. 78). The whole area has previously been interpreted as a large E-W trending anticline plunging westwards, with some minor folds and thrust planes in its core, and cut up into several segments by faults (Bütler, 1948, p. 28).

\section{Kap Tyrrel thrust}

This major thrust plane, first recognised in Kap Tyrrel by Bütler (1948, p. 32), runs from Kap Tyrrel to the Dobbeltvigen Bugt area, striking NNE with a general ESE dip. Beneath this spectacular overthrust, the limestones and dolomites of the multicoloured series are at Kap Tyrrell folded in a recumbent syncline striking NNE; minor co-axial folds have either a fracture or flow axial plane cleavage 


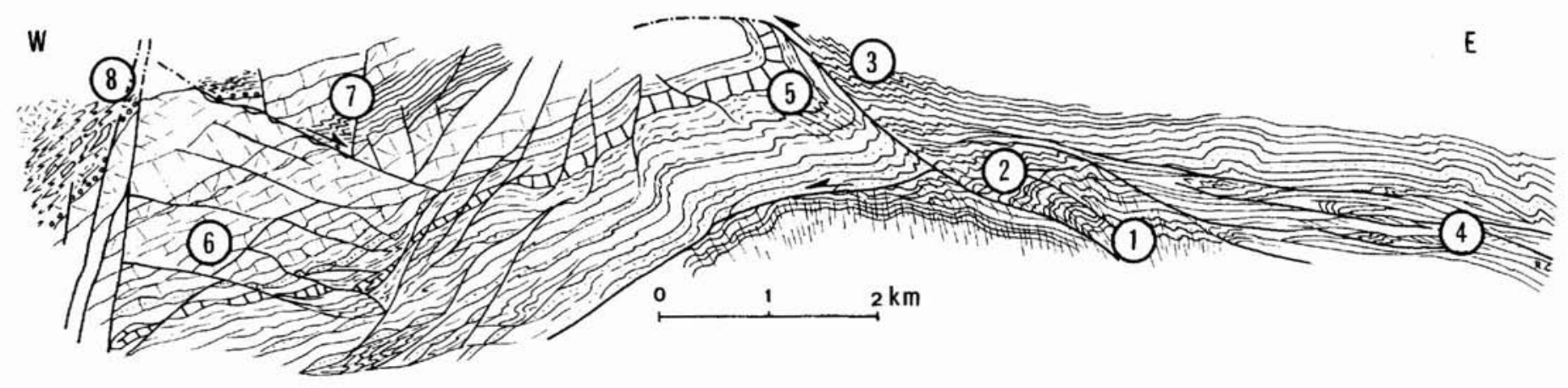

Fig. 3. Diagrammatic section across Canning Land. Black shales of Lower Eleonore Bay Group: 1 - zone of harmonic folding and slaty cleavage; 2 - zone of flexural-slip type open folds; 3 - zone of frontal contraction; 4 - mylonitic stratoid zones and lenses, overlain by unfolded black shales. Upper Eleonore Bay Group: 5 - recumbent sync line of Multicoloured Series below the Kap Tyrrel thrust plane; 6 - limestones and dolomites affected by low-angle normal faults and boudinage. 7 - Lower Cambrian affected by recumbent folding along the main low-angle normal fault. 8 - Lower Devonian with olistolites, affected by syn-sedimentary folding and bounded by late Devonian faults. Dykes and late Devonian and Tertiary faults have been omitted. 
developed, which dips $20^{\circ}$ to $40^{\circ}$ ESE in the red shales. Towards the south-west the thrust plane runs more or less horizontally between two units of black shales with in front of them a moved mass of Upper Eleonore Bay Group sediments (fig. 3). The quartzites are truncated and separated from the lowermost part of the Lower Eleonore Bay Group black shales by a slide gently dipping to the south-west and are affected by NNE striking tight conjugate or knee folds with steep axial planes; these were also recognised by Bütler $(1948, p$. 30). In the same area, the reappearence of black shales above limestones and dolomites by normal faulting south-east of Porfyrbjerg suggests that a flat-lying thrust sheet of black shales may have covered the whole of northern Canning Land.

\section{Structure of the black shales}

Four principal zones of deformation have been recognised in the black shales (see fig. 3). In zone 1, harmonic folding under nearly uniform strain rates occurred. This deepest zone is restricted to the area south-east of Dobbeltvigen Bugt and characterised by a regular sub-vertical slaty cleavage $\mathrm{N}$ to $\mathrm{NE}$ trending, and asymetric folds overturned towards WNW. Open to close folds vary from class $1 \mathrm{C}$ to class 2 (Ramsay, 1967, p. 365), that is to say they are of flexural-slip or similar type, with low height-width ratios from 0.5 to 1 , and low depth to width ratios from 1 to 5 (Hansen, 1971, p. 13). Locally, the slaty cleavage has been seen cutting earlier N-S trending very open folds. The western limbs of some frontal anticlines behind the main thrust plane are overturned, with a gently ESE dipping slaty cleavage.

In zone 2, exposed above and in front of zone 1, the open to tight folds are all of flexural-slip type, with many internal slip surfaces on bedding planes, and small shearing planes covered with slickensides; an irregular (non-axial plane) strain-slip cleavage occasionally occurs, as well as frequent dilation quartz veins in the fold hinges.

The zone 3 is restricted to the frontal part of the overthrust sheet near the thrust plane described above (for example east of Kap Tyrrel). The folds are generally of small scale $(\mathrm{dm})$, irregular, asymmetric and "en chevron", all of flexural-slip type (class 1B, depth to width ratio from 1 to 5 , and height to width ratio less than 0.5 ). Axial planes are often east dipping, with occasional development of a strain-slip cleavage; slickensides on the longer limbs, not necessarily perpendicular to fold hinges, are conspicuous.

The zone 4 includes most of the black shales in Kap Wardlaw and Bowen Bjerg. The beds are flat-lying or gently dip SW or SE. They are strongly affected by differential gliding, with extensive development of mylonitic zones and sheets separated by shear planes or slides with differential displacement of unknown amplitude, which cut bedding surfaces obliquely. 
Structural analysis in the generally compact rocks is difficult, and shows a complex pattern which may be due to varying strain conditions and/or different stages of continuous movement or sliding on bedding surfaces and shear planes.

Within the mylonitic sheets the stratigraphic succession is cleaved into tectonic flat lenses at all scales ( $\mathrm{mm}$ to $100 \mathrm{~m}$ ), for example, north of Bowen Bjerg. West of Kap Wardlaw, the longer axes of the lenses lie parallel to the streaks on beds and shear planes, which show the same mean E-W direction of flow as slickensides in zone 3, with many local disturbances. Intense recumbent to isoclinal disharmonic folds on different scales ( $\mathrm{mm}$ to $20 \mathrm{~m}$ ) occur within the tectonic lenses, with, in many areas, a mean trend parallel to the lengths of the lenses; that is to say, parallel to the flow direction. When respective displacements along shearing planes can be estimated, they concur with an extension of the rock in an E-W direction. North of Bowen Bjerg ptygmatically folded quartz veins and N-S trending vertical veins occur in phyllonitic shales.

A sporadic crenulation cleavage is encountered in the laminated shales including the lenses. This cleavage is well developed west of Kap Wardlaw as an axial plane cleavage of minor folds with a mean $\mathrm{N}-\mathrm{S}$ trend, independent of the trend of the lenses, and dips gently either west or east even in single multilayered beds (fig. 4).

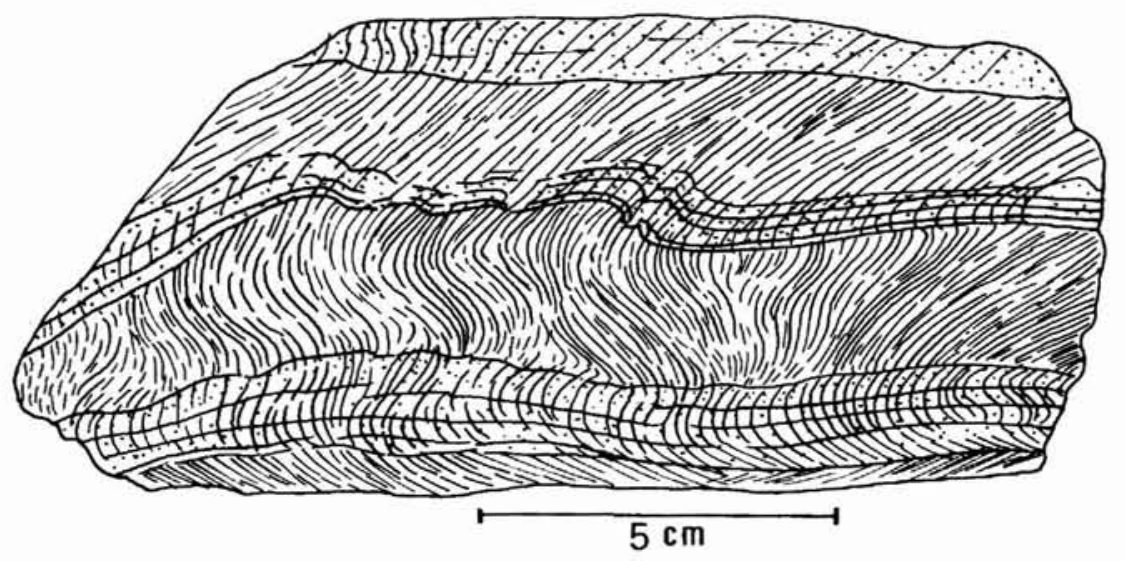

Fig. 4. Relations between slaty cleavage and stratification in a multilayered black quartzitic shale, implying longitudinal unequal strain sub-parallel to the bedding. Zone 4, Kap Wardlaw.

These conspicuous structures are possibly due to differential buckling under longitudinal unequal strains parallel to layer surfaces. Some decimetre scale isoclinal, sometimes disrupted folds related to this cleavage also occur, with highly laminated limbs, and axial plane disposed late quartz veins. In the contact zone of the Kap Wardlaw granite, this cleavage is outlined by flattened andalusite spots and, in the inner zone, by the disposition of biotite in the axial planes of minor 
folds, showing that this second family of folds developed in a late state of deformation during heating of country rock. In Kap Fletcher, highly deformed red and green shales of the Quartzite Series show decametre scale irregular, E-W trending, recumbent to isoclinal similar-type folds with well developed horizontal axial plane flow cleavage. Larger scale mylonitic fabric also occurs in Wegener Halvø. In the eastern cliffs of Kap Brown (alt. $350 \mathrm{~m}$ ) a flat-lying slide between black shales and a lower unit of green shales and quartzites belonging possibly to the Quartzites Series, is outlined by decametre scale boudins and lenses of white quartzite. The underlying green shales are strongly affected by a flat-lying cleavage and are involved in decametre scale recumbent to isoclinal N-S trending folds. Brittle zones and horizontal shear planes of normal fault type occur parallel to cleavage, and agree with an E-W extension.

All these different structures seem to have developed during the same phase but under very heterogeneous strain. Refolded mylonitic structures of zone 4 , for example, have nowhere been seen in zones 1,2 or 3 .

\section{Folding and the Kap Wardlaw granite}

The Kap Wardlaw granite cuts sharply across the black shales with mylonitic structure of zone 4, and the quartzite affected by some open box folds trending NNE to E. Many features point to a late-kinematic "mise en place" of magmatic rocks: 1) flattened spots of andalusite; 2) synkinematic biotite in hornfelses; 3) boudinage of lamprophyric foliated sills cutting banded hornfelses with mylonitic structure, and development of an arteritic-leucocratic melting zone in the "pressure shadows" of the segmented parts of the body; 4) sub-horizontal flow structure and, occasionally, NNE trending linear disposition of biotite in the Kap Wardlaw granite; 5) NNE trending pegmatites in tension gashes. These features strongly support the evidence that the granite dykes and the granite itself were emplaced in a late stage of the deformation sequence described above, and cannot be seen as post-tectonic.

\section{Structures of the Upper Eleonore Bay Group to Cambrian rocks}

The main tectonic features are large-scale boudinage of the whole succession correlated with weakly inclined normal faults. At the bottom of Ålborg Fjord for example, extensive formation of boudins or tectonic lenses occurs especially in bed groups 7 to 13 of the Multicoloured Series, in relation to shear planes and normal faults sub-parallel or discordant to the bedding. 
The dark limestones of bed groups 9 to 11 are sheared into flat tectonic lenses and have suffered a disharmonic plastic deformation, characterised by irregular and curved recumbent to isoclinal folds with a mean WNW-ESE trend, together with extensive development of calcitic and dolomitic tension veins with an extension in a WSW-ENE direction.

Normal faults and slides are most spectacular at Kap Fletcher allowing the preservation of Cambrian beds, dipping about $35^{\circ}$ to SW. The fault dips $30^{\circ}$ to the east with at least $1.5 \mathrm{~km}$ horizontal displacement. Near the fault the plastic Lower Cambrian shales and banded silts are isoclinally folded by N-S trending similar folds with sub-horizontal axial plane cleavage.

A poorly developed slaty cleavage gently dipping either to ESE or to WNW and locally observed in red shales of the Multicoloured Series seems to be related to differential sliding on bedding planes.

\section{Structure of the early Devonian sediments'}

These sediments are also affected by the main low-angle normal fault of Kap Fletcher. The rocks are highly deformed and have been isoclinally folded while still unconsolidated water-rich sediments. This is evident from the occurrence of microfolded dolomites or axial plane disposed black cherts in recumbent smallscale folds. In the biotitic tuffs, a flattening parallel to the bedding occurs, and a slaty axial plane cleavage to small-scale plastic folds which plunge $30^{\circ}$ westwards has been observed in the black shales north-east of Søndre Basisdal.

These structures appear to have formed under high-pressure conditions, which may have been reached under a thick pile of thrusted early Devonian sediments, or under gravity nappes of pre-Devonian rocks.

\section{Post-Middle Devonian structures}

Intensive extension occurred in post-Devonian time, normal faulting took place, and many pre-existing faults and slides in the pre-Devonian sediments moved again.

Porfyrbjerg represents half of a basin-like graben structure, and minor graben and horsts occur north-east of Wegener Halvø. The structures may have developed at the border of a large graben extending westwards under the more recent terrain of Jameson Land, rather than the southern limit of a northern "down flexed tract" as has been suggested by Haller (1970, fig. 40). The chevron folds observed are related to the normal faults and are evidence of the adaptation of these sediments to strong vertical differential movements without any regional compression, in contrast to some areas of the fjord region where compressive folds and thrusts have been described (Bütler, 1955, p. 60). 


\section{Infracrustal rocks in Canning Land}

The nature of deep-seated levels of the Caledonian fold belt can be inferred from the occurrence of many crystalline xenoliths found in some lamprophyric dykes near Porfyrbjerg and in Porfyrdal. The xenoliths up to $0.5 \mathrm{~m}$ in size comprise coarse-grained, fresh, often garnetiferous, orthoclase-, kyanite- and sillimante- bearing gneisses, possibly of high-pressure granulite facies metamorphic grade. Some granite, biotitic schists and gneisses, and amphibolitic rocks have also been found together with high-grade hornfelses, white sandstone and quartzite fragments derived from the Eleonore Bay Group.

\section{Tertiary dykes}

A few vertical generally $\mathrm{N}-\mathrm{S}$ trending dykes have been encountered. The thicker dykes (up to $5 \mathrm{~m}$ ) are often banded and include porphyric doleritic rocks of various grain size, and contain centrally either large calcic plagioclase up to $5 \mathrm{~cm}$ across, or pyroxene or biotite, with calcitic amygdales. South-east of Porfyrbjerg, one dyke has been sheared by the main late Tertiary NW-SE trending fault.

\section{Mineralisations}

Many indications of copper mineralisation were found, the only significant ones being copper-bearing green shales and silty shales, a recurrent facies in the lower part of the Upper Eleonore Bay Group. However, the copper content seems to be low and no concentrations yielding workable segretations have been recorded.

\section{Concluding remarks}

\section{Stratigraphy}

The entire succession from the lowest black shales to the Cambrian dolomites seem to represent very shallow-water deposits characteristic of shelf-type conditions with many sub-continental deposits (shales with ripple-marks, sun-cracks, deltaic channels) and sub-tidal facies in stromatolitic biostromes. No part of the succession suggests geosynclinal-type sedimentation.

Any correlation with the metasedimentary sequence of Liverpool Land is highly speculative. Some banded, quartzitic, biotitic schists and hornfelses which were found in large septa in the red porphyric granodiorite of western Liverpool Land $\left(71^{\circ} 08^{\prime} \mathrm{N} ; 22^{\circ} 14^{\prime} \mathrm{W}\right)$ contain decimetre size paches of calc-silicate, diopside-bear- 
ing rocks, very similar in form and size to the small channels or "wash-outs" recorded in the basal black shales; they have a similar aspect and similar mineral association in the contact zone of the Kap Wardlaw granite.

Mutual relations of dykes point to a genetic association between acid, semi-basic and lamprophyric dykes post-dating the main volcanics of Porfyrbjerg and Søndre Basisdal, but pre-dating the emplacement of the Kap Wardlaw granite. The affinities between the red porphyric rocks of Canning Land and the red Hurry Inlet granite have already been pointed out by Noe-Nygaard (1937, p. 134).

\section{Structure}

While a gradual increase of deformation is evident descending from the LimestoneDolomite Series to the Lower Eleonore Bay Group shales, the different types of structures recorded in the zones 1 to 4 pass laterally from one to another, suggesting that they formed at similar levels. Nowhere has polyphase deformation been recognised. It is emphasised that the very different structures formed under very inhomogeneous strain conditions involving various mechanisms of folding. In zone 4, the mylonitic fabric formed during gliding processes, with local strain parallel to layer boundaries giving an E-W mean direction of flow and a correlateable sub-vertical shortening realised by small-scale intra-mylonitic folds. It is suggested that such patterns may have formed under passive conditions in gliding units emplaced by gravity. The highly deformed stratoïd zones are zones where the total amount of deformation is expressed, giving superimposed-like conditions correlated with independent strain conditions on either side of shear planes with independent fold development. These folds of zone 4 formed during short periods of contraction during gliding processes, which did not stop before the heating of country rock preceding intrusion of the Kap Wardlaw granite. It must be stressed however that the mechanism of transverse E-W trending folding parallel to flow is conjectural, but it is suggested that if such structures also developed in deeper and high-metamorphic conditions, the transverse E-W trending isoclinal folding recorded in many areas of the Central Metamorphic Complex (Haller, 1957) and south of the Stauning Alper (Henriksen \& Higgins, 1970, p. 12) might be explained in the same way.

The folds of zone 3 formed by frontal contraction at the end of emplacement of the gliding unit, limited to the west by a major thrust plane. The compressive folds of zone 1 formed under more homogeneous strain under deeper conditions.

Comparing the tectonic features in Canning Land with those described in the superstructure of the fjord region, the following remarks can be made:

- The total shortening of $5.3 \%$ calculated by Eha $(1953$, p. 91$)$ does not take into account vertical correlated extension: this very low shortening could be apparent and due only to vertical extension. 
- Weakly dipping normal faults correlated with folds have been frequently recorded in the superstructure. On a section given by Fränkl (1953, p. 42), the widening due to normal flat faults may be estimated to about $100 \%$ in the "klippen" of the Multicoloured Series, with a sub-vertical maximum compression. The sections 1 to 4 of Pl. II given by Fränkl (1953), show no shortening but point to a subhorizontal E-W extension which is the main tectonic event.

- In Canning Land, the mylonitic structure of the black shales does not allow an accurate calculation of the bulk deformation, but owing to the widespread development of boudinage and other related extension features, it can be stressed that a considerable amount of widening with large westwards translation occurred.

It is emphasised that extension and associated gravity gliding processes are a common and typical feature of the whole superstructure of the Caledonian fold belt, apparently in close connection with the emplacement of migmatitic culminations and tumours which rose in the Central Metamorphic Complex (Haller, 1970 , p. 80 ), possibly acting only by buoyant forces from depth as argued by Ramberg (1967, p. 127).

\section{References}

Bütler, H. 1948: Notes on the geological map of Canning Land (East Greenland). Meddr Gronland 133, 2, $97 \mathrm{pp.}$

Bütler, H. 1955: Das Variscisch gefaltete Devon zwichen Duséns Fjord und Kongeborgen in Zentral-Ostgrönland. Meddr Gronland 155, 1, $131 \mathrm{pp}$.

Eha, S. 1953: The pre-Devonian sediments on Ymers $\emptyset$, Suess Land, and Ella $\emptyset$ (East Greenland) and their tectonics. Meddr. Gronland 111, 2, $105 \mathrm{pp}$.

Fränkl, E. 1953: Die geologische Karte von Nord-Scoresby Land (NE-Grønland). Meddr Grønland 113, 6.

Haller, J. 1957: Gekreuzte Faltensysteme in Orogenzonen. Schweiz. Min. Petr. Mitt. 37, 1, 11-34.

Haller, J. 1970: Tectonic map of East Greenland (1:500,000). Meddr Gronland 171, 5, 286 pp.

Hansen, E. 1971: Strain facies. Springer Verlag, Berlin.

Henriksen, N. \& Higgins, A. K. 1970: Preliminary results of mapping in the crystalline complex of Renland, the southern Stauning Alper and south-west Liverpool Land, Scoresby Sund, East Greenland. Rapp. Gronlands geol. Unders. 30, 5-17.

Katz, H.R. 1952: Zur Geologie von Strindbergs Land (NE-Grönland). Meddr Gronland $111,1.150 \mathrm{pp}$.

Noe-Nygaard, A. 1937: Die palaeozoischen Eruptivgesteine von Canning-Land. Meddr Gronland $118,6.153 \mathrm{pp}$.

Nordenskjöld, O. 1907: On the geology and physical geography of East-Greenland. Meddr Gronland 28, 5, 151-284.

Poulsen, C. 1930: Contributions to the stratigraphy of the Cambro-Ordovician of East Greenland. Meddr Gronland 74, 297-316. 
Ramberg, H. 1967: Gravity, deformation and the Earth's crust as studies by centrifuged models. Acad. Press, London.

Ramsay, J. G. 1967: Folding and fracturing of rocks. McGraw Hill, London. 